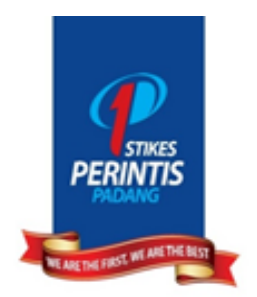

Contents list available at JKP website

Jurnal Kesehatan Perintis (Perintis's Health Journal)

Journal homepage: https://jurnal.stikesperintis.ac.id/index.php/JKP

\title{
Lepas Drain Dini Terhadap Kualitas Hidup Pasien Kanker Payudara Pasca Operasi Modified Radical Mastectomy (MRM)
}

\author{
Ramadanus*, Daan Khambri, Wirsma Arif Harahap \\ Universitas Andalas, Sumatera Barat, Indonesia \\ RSUP Dr. M. Djamil Padang, Sumatera Barat, Indonesia
}

Article Information :

Submission:Jun 4, 2020; Revised:Jul 11, 2020; Accepted:Jul 11, 2020; Available online:Jul 12, 2020

*Corresponding author : dr. rama.danus@gmail.com

\begin{abstract}
ABSTRAK
Pemasangan drain setelah operasi Modified Radical Mastectomy (MRM) bertujuan untuk mengurangi pembentukan seroma, namun di sisi lain dapat menyebabkan nyeri dan ketidaknyamanan serta mempengaruhi kualitas hidup pasien. Belum ada penelitian di Indonesia mengenai kapan sebaiknya drain dilepas dan bagaimana hubungannya dengan kualitas hidup pasien. Penelitian ini bertujuan mengetahui hubungan lepas drain dini dengan kualitas hidup pasien pasca operasi MRM; Penelitian ini merupakan penelitian nested cohort pada 40 pasien kanker payudara yang menjalani operasi MRM. Pasien dibagi atas 2 kelompok; lepas drain hari I dan hari III pasca operasi. Semua pasien dipulangkan pada hari III. Dilakukan penilaian kualitas hidup pasien 7 hari setelah pasien dipulangkan menggunakan Kuesioner EORTC QLQ-C30 meliputi skala gejala, skala fungsi dan skala kesehatan secara umum. Skor skala gejala kelompok pasien lepas drain hari I lebih rendah dan berbeda bermakna daripada hari III $(7,75 \pm 3,19$ vs $11,25 \pm 3,58)(p 0,002)$ namun tidak berbeda bermakna pada skala fungsional $(86,50 \pm 3,03$ vs $86,35 \pm 2,86)(p 0,869)$ dan kualitas hidup secara umum $(72,92 \pm 10,06$ vs $71,67 \pm 8,29)$ ( $p 0,671)$. Terdapat hubungan bermakna lepas drain dini dengan kualitas hidup pasien dalam skala gejala. Kualitas hidup pasien lepas drain hari I lebih baik daripada lepas drain hari III.
\end{abstract}

Kata kunci: kanker payudara, modified radical mastectomy, lepas drain dini, kualitas hidup, EORTC QLQ-C30

\begin{abstract}
Installation of drainage after Modified Radical Mastectomy (MRM) surgery has been aimed to reduce seroma formation. It can cause pain, discomfortness and affect patinet's quality of life. There is no study in Indonesia about early drain removal and how it relates to patient's clinical outcome. This study aims to determine the association of early drain removal with quality of life of patients after MRM surgery. This is a nested cohort study on 40 breast cancer patients underwent MRM surgery. Patients were divided into 2 groups; off-drain day-I and day-III post surgery. Patients were discharged on day-III. Quality of life was assessed 7 days after discharged using EORTC QLQ 30 quetionaire including symptom scale, functional scale dan global quality of life scale. Symptom scale score of the off-drain day-l group was significantly lower than day-III group (7.75 \pm 3.19 vs. 11.25 \pm 3.58$)(p 0.002)$ but did not differ in
\end{abstract}

(c) Jurnal Kesehatan Perintis (Perintis's Health Jornal)-ISSN : 2622-4135. All rights reserved 


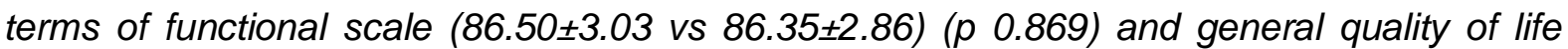
significantly (72.92 \pm 10.06 vs $71.67 \pm 8.29$ ) (p 0.671); Early drain removal is significantly associated to patient's quality of life in term of symptom scale. Symptom scale of off-drain day-I group was better than day-III group.

Keywords: breast cancer, modified radical mastectomy, early drain removal, quality of life, EORTC QLQ 30

\section{PENDAHULUAN}

Kanker payudara merupakan kanker dengan jumlah tertinggi pada perempuan di dunia (Khambri, 2015). Di Indonesia kanker payudara merupakan jenis kanker terbanyak, baik pada perempuan saja maupun pada seluruh populasi (laki-laki dan perempuan) (Wahidin, 2017). Di RSUP Dr. M Djamil Padang pada tahun 2013 terdapat 253 pasien kanker payudara yang datang berobat, di mana $77,2 \%$ merupakan stadium lanjut (stadium III dan IV) dan 22,8 $\%$ merupakan stadium dini (stadium I dan II) (Khambri, 2015).

Pembedahan merupakan terapi utama pada kanker payudara yang masih operable. Berbagai jenis pembedahan yang dilakukan meliputi mastektomi simpel, mastektomi radikal klasik, modified radical mastectomy (MRM), kuadrantektomi dan lumpektomi. MRM merukapan tindakan pembedahan yang paling sering dilakukan di antara modalitas pembedahan lain (Peraboi, 2014). Di RSUP Dr. M Djamil Padang, pada periode September 2018 sampai Agustus 2019, 73\% dari semua tindakan pembedahan kanker payudara adalah MRM. Sehubungan dengan pembiayaan kesehatan di era JKN saat ini, rujukan pasien dari fasilitas kesehatan tingkat I melalui fasilitas kesehatan tingkat 2 sehingga diperkirakan jumlah operasi MRM lebih banyak lagi di kota Padang (Divisi Onkologi RSUP Dr. M Djamil Padang, 2019).

Salah satu komplikasi pasca MRM yang paling sering terjadi adalah terbentuknya seroma (Srivastava, V., et al, 2012). Beberapa cara digunakan untuk mengurangi terbentuknya seroma, salah satu yang rutin dilakukan adalah dengan dengan memasang drain (Azamris, 2015). Segera setelah MRM drain akan dipasang untuk mengurangi seroma. Dengan hal ini diharapkan akumulasi cairan dan pembentukan seroma dapat berkurang. Di sisi lain alat drain itu sendiri merupakan benda asing yang dapat menimbulkan ketidaknyamanan, rasa nyeri pada pasien serta memperlama masa rawatan dan menigkatkan biaya, hal ini akan berdampak pada kualitas hidup pasien (Kurnia, A., et al, 2016).

Kualitas hidup mengacu pada hasil psikososial, emosional, dan fisik dari perawatan kesehatan seperti yang dirasakan oleh pasien. Kanker payudara adalah salah satu kondisi kronis yang dapat mempengaruhi kualitas hidup pasien. Kanker payudara berpotensi mengancam jiwa, dan diagnosis serta pengobatannya dapat memiliki efek dramatis pada aspek fisik, psikologis, sosial dan finansial kehidupan (Sampatharaju, S. Et al, 2010). Pasien dengan kanker payudara dapat memiliki masalah fisik dan emosional, kegiatan sosial dan pekerjaan oleh penyakit itu sendiri, atau dapat berhubungan dengan pengobatan kanker seperti pembedahan, radioterapi, kemoterapi dan terapi hormon (El Fakir, Sarima., et al, 2016).

Kualitas hidup pasien kanker payudara dapat dipengaruhi oleh berbagai faktor. Penelitian Taira dkk (2011) mendapatkan faktor yang berhubungan dengan kualitas hidup pasien kanker payudara salah satunya adalah pembedahan (Taira, N., et al, 2011). Penelitian Juwita dkk (2018) di Padang mendapatkan kualitas hidup pasien kanker payudara tidak berhubungan dengan karakteristik demografis (umur, tingkat pendidikan, lama terdiagnosis) tetapi berhubungan dengan karakteristik klinis (kemoterapi dan siklus kemoterapi) hanya saja tidak dilakukan penilaian hubungan kualitas hidup dengan pembedahan (Juwita, DA., et al, 2018).

Saat ini terdapat kecenderungan untuk melepas drain dini untuk meningkatkan kualitas hidup pasien. Vos, H., dkk mendapatkan bahwa melepas drain dini dapat meningkatkan kualitas hidup dan 
mengurangi kebutuhan untuk rawatan home care pasien kanker payudara pasca operasi MRM (Vos, Hanne., 2018). Sangat sedikit penelitian mengenai hubungan lepas drain dini dengan kualitas hidup pasien pasca operasi MRM. Di Indonesia belum ada penelitian yang menilai hubungan waktu lepas drain dini dengan kualitas hidup pasien kanker payudara. Penelitian ini bertujuan untuk menilai hubungan lepas drain dini dengan kualitas hidup pasien kanker payudara pasca operasi MRM.

\section{METODE PENELITIAN}

Penelitian ini merupakan studi analitik prospektif, nested cohort di RSUP Dr. M. Djamil Padang pada periode November 2019 - Januari 2020. Subjek penelitian ini adalah pasien yang didiagnosis dengan kanker payudara berdasarkan histopatologis yang dilakukan operasi MRM. Terdapat total 40 sampel yang dibagi menjadi 2 kelompok; kelompok lepas drain hari I dan lepas drain hari III masing-masing 20 orang. Sampel diambil secara consecutive sampling, dimana semua subjek yang datang dan memenuhi kriteria pemilihan dimasukkan dalam penelitian sampai jumlah subjek yang diperlukan terpenuhi. Kriteria inklusi meliputi; pasien telah didiagnosis dengan kanker payudara secara histopatologis; menjalani operasi Radical Modified Mastectom. Pasien dengan penyakit penyerta (diabetes mellitus, hipertensi, morbid obesity) dieksklusi dari penelitian ini.

Variabel bebas adalah waktu lepas drain dini yang didefinisikan sebagai waktu dihitung dari awal drain dipasang saat operasi sampai drain dilepas, yaitu 1 hari dan 3 hari. Variabel tergantung adalah kualitas hidup pasien. Seroma didefinisikan sebagai terkumpulnya cairan serosa di bawah flap atau di daerah axilla yang mengisi dead space setelah dilakukan tindakan mastektomi. Penelitian ini menilai seroma secara klinis, yaitu dikatakan seroma jika simptomatis, mengganggu pasien, palpable, fluktiatif atau tensil dan memerlukan paling tidak sekali aspirasi (Sampatharaju, S., et al, 2010). Kualitas hidup didefinisikan sebagai pencapaian seorang individu ditinjau dari status fisik, peran, kognitif, emosi, sosial, kesehatan secara global, serta gejala secara karakteristik demografi (Juwita, DA., et al, 2018; Saptaningsih, et al, 2018)

Kualitas hidup pasien kanker payudara diukur menggunakan kuesioner European Organisation for Research and Treatment of Cancer Quality of Life Questionnaire Core 30 (EORTC QLQ-C30) versi bahasa Indonesia yang diadopsi dari EORTC QLQC30 Scoring Manual version 3.0 (Chopra, I., et al 2012). Kuisioner EORTC QLC-30 telah diuji reliabilitas dan validitasnya di Indonesia oleh Perwitasari dkk (2011) dan di negara lain oleh Tan dkk (2014). EORTC QLQ-C30 terdiri dari 30 pertanyaan yang digunakan dalam mengukur berbagai aspek dalam kualitas hidup. Pertanyaan tersebut diklasifikasikan menjadi 15 dimensi, yaitu: lima skala fungsional (fisik, peran, emosional, kognitif, dan sosial), tiga skala gejala (kelelahan, nyeri, dan mual atau muntah), satu skala kesehatan umum, dan enam item tunggal yang menangani berbagai gejala dan dampak keuangan yang dirasakan oleh pasien. Skor yang lebih tinggi menunjukkan tingkatan yang lebih baik pada skala fungsional dan status kesehatan umum, namun lebih buruk pada skala gejala. (Perwitasari, DA., et al, 2011; Tan, ML., et al, 2014).

Penelitian ini telah mendapatkan Keterangan Lulus Kaji Etik dari Komite Etik Penelitian Kesehatan RSUP Dr. M Djamil Padang. Operasi MRM dilakukan pada semua pasien sesuai dengan Panduan Praktek Klinis yang berlaku. Setelah operasi dipasang elastic bandage 1 buah ukuran 6 inci pada semua pasien di kedua kelompok. Kualitas hidup dinilai pada kontrol pertama 7 hari seelah pulang rawatan. Hubungan lepas drain dini dengan kualitas hidup pasien dianalisis menggunakan uji $\mathrm{T}$ independen pada distribusi data dan uji normalitas normal. Uji statistik dilakukan pada derajat kepercayaan $95 \% \mathrm{Cl}$, apabila nilai $\mathrm{p}<$ 0,05 , maka hipotesis diterima.

\section{HASIL DAN PEMBAHASAN}

Rerata umur subjek penelitian pada kelompok lepas drain hari I yaitu $47,55 \pm 7,36$ tahun dan lepas drain hari III yaitu $46,95 \pm 7,79$ tahun. Lebih dari separuh $(55,0 \%)$ subjek penelitian memiliki 
pendidikan tamat SMA baik pada lepas drain hari I dan III. Lebih dari separuh responden $(55,0 \%)$ pada kelompok lepas drain hari I adalah ibu rumah tangga dan kurang dari separuh responden $(45,0 \%)$ pada kelompok lepas drain hari III. Rerata IMT subjek penelitian pada kelompok lepas drain hari I yaitu $23,61 \pm 2,37$ dan lepas drain hari III yaitu $24,19 \pm 1,28$. Kurang dari separuh responden $(40,0 \%)$ pada kelompok lepas drain hari I dengan stadium Illa dan separuh responden $(50,0 \%)$ pada kelompok lepas drain hari III dengan stadium IIIa. Lebih dari separuh responden memiliki histopatologi dengan invasive ca of NST pada kelompok lepas drain hari I $(75,0 \%)$ dan pada kelompok lepas drain hari III $(80,0 \%)($ Tabel 1$)$.

Tabel 1. Karakteristik Pasien Kanker Payudara Pasca Operasi MRM

\begin{tabular}{|c|c|c|c|}
\hline Variabel & $\begin{array}{c}\text { Lepas Drain } \\
\text { Hari I } \\
(n=20)\end{array}$ & $\begin{array}{l}\text { Lepas Drain Hari III } \\
\qquad(n=20)\end{array}$ & $p$ value \\
\hline Umur (tahun), mean $\pm S D$ & $47,55 \pm 7,36$ & $46,95 \pm 7,79$ & $0,804^{a}$ \\
\hline \multicolumn{4}{|l|}{ Pendidikan, f(\%) } \\
\hline Tamat SD & $2(10,0)$ & $2(10,0)$ & \multirow{4}{*}{$0,783^{b}$} \\
\hline Tamat SMP & 0 & $1(5,0)$ & \\
\hline Tamat SMA & $11(55,0)$ & $11(55,0)$ & \\
\hline Tamat PT & $7(35,0)$ & $6(30,0)$ & \\
\hline \multicolumn{4}{|l|}{ Pekerjaan, f(\%) } \\
\hline PNS & $7(35,0)$ & $6(30,0)$ & \multirow{4}{*}{$0,365^{\mathrm{b}}$} \\
\hline Pegawai swasta & $1(5,0)$ & $5(25,0)$ & \\
\hline Ibu rumah tangga & $11(55,0)$ & $9(45,0)$ & \\
\hline Petani & $1(5,0)$ & 0 & \\
\hline Indeks Massa Tubuh & $23,61 \pm 2,37$ & $24,19 \pm 1,28$ & $0,344^{\mathrm{a}}$ \\
\hline \multicolumn{4}{|l|}{ Stadium } \\
\hline 1 & $1(5,0)$ & $1(5,0)$ & \multirow{4}{*}{$0,916^{b}$} \\
\hline lia & $5(25,0)$ & $1(5,0)$ & \\
\hline lib & $6(30,0)$ & $8(40,0)$ & \\
\hline IIla & $8(40,0)$ & $10(50,0)$ & \\
\hline \multicolumn{4}{|l|}{ Histopatologi } \\
\hline Invasive NST & $15(75,0)$ & $16(80,0)$ & \multirow{3}{*}{$0,744^{\mathrm{b}}$} \\
\hline Invasive Ductal & $1(5,0)$ & $1(5,0)$ & \\
\hline Invasive Lobular & $4(20,0)$ & $3(15,0)$ & \\
\hline
\end{tabular}

Setelah dilakukan uji statistik tidak terdapat perbedaan dari semua karakteristik antara kelompok lepas drain hari I dan kelompok lepas drain hari III. Dengan demikian disimpulkan bahwa subjek penelitian homogen.

Rerata skor skala fungsi pasien dengan lepas drain hari I yaitu 86,50 $\pm 3,03$ hampir sama dibandingkan lepas drain hari III yaitu $86,35 \pm 2,86$. Berdasarkan hasil uji statistik dengan mengunakan independent sample $T$ test didapatkan nilai $\mathrm{p}=0,869$ $(p>0,05)$ maka dapat disimpulkan tidak terdapat hubungan bermakna antara lepas drain dini dengan skala fungsional pasien kanker payudara pasca operasi MRM.

Rerata skor skala gejala pasien dengan lepas drain hari I yaitu $7,75 \pm 3,19$ lebih rendah daripada pasien dengan lepas hari III yaitu $11,25 \pm 3,58$. Berdasarkan hasil uji statistik dengan mengunakan independent sample $T$ test didapatkan nilai 
$\mathrm{p}=0,002(\mathrm{p}<0,05)$ maka dapat disimpulkan terdapat hubungan bermakna antara lepas drain dini dengan skala gejala pasien kanker payudara pasca operasi MRM, dimana pasien lepas drain hari I memiliki skor skala gejala yang lebih baik.

Rerata skor skala kesehatan umum (QoL) pasien dengan lepas drain hari I yaitu $72,92 \pm 10,06$ dibandingkan lepas drain hari III yaitu $71,67 \pm 8,29$. Berdasarkan hasil uji statistik dengan mengunakan independent sample $T$ test didapatkan nilai $\mathrm{p}=0,671$ $(p>0,05)$ maka dapat disimpulkan tidak terdapat hubungan bermakna antara lepas drain dini dengan skala kesehatan umum pasien kanker payudara pasca operasi MRM (Tabel 2).

Terdapat perbedaan bermakna pada rerata nilai skala gejala antara kelompok lepas drain hari I dan kelompok lepas drain 3, dimana kelompok lepas drain hari I menunjukkan rerata nilai yang lebih rendah. Pada skala gejala semakin rendah nilai maka semakin baik penilaian. Pada skala gejala dilakukan penilaian terhadap beberapa gejala pada pasien meliputi kelelahan, mual dan muntah, nyeri, dispneu, insomnia, penurunan nafsu makan, konstipasi, diare dan kesulitan keuangan. Uji statistik pada penelitian ini menunjukkan waktu lepas drain dini secara bermakna berhubungan dengan gejalagejala di atas.

Meskipun penelitian pembanding masih sangat sedikit, namun hasil penelitian ini sesuai dengan penelitian tersebut. Penelitian Ackroyd dan Reed (1997) mendapatkan bahwa $81 \%$ pasien lebih memilih melepaskan drain dini dilanjutkan aspirasi seroma di poliklinik bila diperlukan (Ackyord, R., et al, 1997). Sedangkan penelitian Vos dkk (2018) mendapatkan perbedaan bermakna pada kualitas hidup pasien antara lepas drain dini dan pasien lepas drain output-based pada beberapa hal. Pertama, pasien lepas drain dini merasakan lebih sedikit nyeri bahu; kedua, pasien lepas drain dini merasa lebih mobile dibandingkan dengan lepas drain output-based; ketiga, pasien lepas drain dini memerlukan lebih sedikit layanan home-care.

Tabel 2. Hubungan Lepas Drain Dini pada hari I dan III dengan Kualitas Hidup Pasien Kanker Payudara Pasca Operasi MRM pada Follow-up 7 hari Post Rawatan

\begin{tabular}{|c|c|c|c|}
\hline Kualitas Hidup & $\begin{array}{c}\text { Lepas Hari I }(n=20) \\
\text { Mean } \pm S D\end{array}$ & $\begin{array}{c}\text { Lepas Hari III } \\
(n=20) \\
\text { Mean } \pm \text { SD }\end{array}$ & p value \\
\hline Skala Fungsional & $86,50 \pm 3,03$ & $86,35 \pm 2,86$ & $0,869 * d$ \\
\hline Skala Gejala & $7,75 \pm 3,19$ & $11,25 \pm 3,58$ & $0,002^{d}$ \\
\hline Skala Kesehatan Umum & $72,92 \pm 10,06$ & $71,67 \pm 8,29$ & $0,671^{d}$ \\
\hline
\end{tabular}

Hanya saja kedua penelitian di atas tidak menggunakan kuesioner yang terstandar untuk menilai kualitas hidup pasien (Vos, $\mathrm{H}$., et al, 2018). Penelitian Pihlmann dkk, 2018 mendapatkan bahwa melepas drain bahkan beberapa jam setelah mastektomi tidak menyebabkan peningkatan jumlah produksi seroma dan bermanfaat mengurangi ketidaknyamanan pasien akibat pemasangan drain (Pihlmann, et al, 2018).

\section{KESIMPULAN}

Lepas drain dini pascaoperasi MRM berhubungan dengan kualitas hidup pasien dalam skala gejala, tetapi tidak berhubungan dalam skala fungsional dan kesehatan umum. Melepas drain dini dapat dipertimbangkan untuk mengurangi gejala yang dirasakan pasien kanker payudara terkait pemasangan drain pasca operasi MRM.

\section{REFERENSI}

Ackroyd, R., \& Reed, M. W. R. (1997). A prospective randomized trial of the management of suction drains following breast cancer surgery with axillary clearance. The Breast, 6(5), 271-274. 
Azamris. (2015). Perbandingan Efektifitas Lama Pemakain Drain Pasif untuk Mencegah Seroma Pasca-Modified Radical Mastectomy. CDK-225. Vol. 42;92-95.

Chopra, I., \& Kamal, K. M. (2012). A systematic review of quality of life instruments in long-term breast cancer survivors. Health and quality of life outcomes, 10(1), 14.

Data Internal Divisi Onkologi Bagian Bedah RSUP Dr. M. Djamil. Padang (2019).

El Fakir, S., El Rhazi, K., Zidouh, A., Bennani, M., Benider, A., Errihani, H., ... \& Nejjari, C. (2016). Health-related quality of life among breast cancer patients and influencing factors in Morocco. Asian Pacific journal of cancer prevention: APJCP, 17(12), 5063.

Juwita, D. A., Almahdy, A., \& Afdhila, R. (2018). Pengaruh Karakteristik Pasien Terhadap Kualitas Hidup Terkait Kesehatan Pada Pasien Kanker Payudara di RSUP Dr. M. Djamil Padang, Indonesia. Jurnal Sains Farmasi \& Klinis, 5(2), 126-133.

Khambri D. (2015). Hubungan Ekspresi Androgen Receptor dengan Faktor Prognostik karsinoma payudara di Sumatera Barat. Padang; Disertasi. Universitas Andalas.

Kurnia, A., Suhandi, A., \& Budiningsih, S. (2016). Correlation between Obesity and Seroma Following Modified Radical Mastectomy. The New Ropanasuri Journal of Surgery, 1(1), 36.

Peraboi. (2014). Panduan Penatalaksanaan Kanker Payudara. Sagung Seto. Jakarta.

Perwitasari, D. A., Atthobari, J., Dwiprahasto, I., Hakimi, M., Gelderblom, H., Putter, H., ... \& Kaptein, A. A. (2011). Translation and validation of EORTC QLQ-C30 into Indonesian version for cancer patients in Indonesia. Japanese journal of clinical oncology, 41(4), 519-529.

Pihlmann, C., Nørby, L., Mertz, B., \& Bigaard, J. (2018). Mastectomy without surgical drainage is safe and feasible. European Journal of Cancer, 92, S21.

Sampatharaju, S., \& Rodrigues, G. Seroma formation after mastectomy: pathogenesis and prevention. Indian journal of surgical oncology, 2010, 1(4), 328-333

Saptaningsih, A. B., Setiawan, D., Rivany, R., Aryandono, T., Atthobari, J., \& Dwiprahasto, I. (2018). The Development of Quality of Life Questionnaire for Indonesian Breast Cancer Patients: INA-BCHRQoL. Asian Pacific journal of cancer prevention: APJCP, 19(5), 1269.

Srivastava, V., Basu, S., \& Shukla, V. K. (2012). Seroma formation after breast cancer surgery: what we have learned in the last two decades. Journal of breast cancer, 15(4), 373-380.

Taira, N., Shimozuma, K., Shiroiwa, T., Ohsumi, S., Kuroi, K., Saji, S., ... \& Katsumata, N. (2011). Associations among baseline variables, treatmentrelated factors and health-related quality of life 2 years after breast cancer surgery. Breast cancer research and treatment, 128(3), 735-747.

Tan, ML., Idris, D. B., Teo, L. W., Loh, S. Y., Seow, G. C., Chia, Y. Y., \& Tin, A. S. (2014). Validation of EORTC QLQC30 and QLQ-BR23 questionnaires in the measurement of quality of life of breast cancer patients in Singapore. Asia-Pacific journal of oncology nursing, 1(1), 22..

Vos, H., Smeets, A., Neven, P., Laenen, A., Vandezande, L., \& Nevelsteen, I. (2018). Early drain removal improves quality of life and clinical outcomes in patients with breast cancer-Results from a randomised controlled trial. European Journal of Oncology Nursing, 36, 112-118.

Wahidin, M., et al. (2017). Situasi Kanker Payudara di Indonesia dan Upaya Pengendaliannya, dalam: Manajemen Terkini Kanker Payudara. Jakarta: Media Aesculapius. 